\title{
ORIGINAL ARTICLE \\ Outcome assessment in conservatively managed patients with cervical spine tuberculosis
}

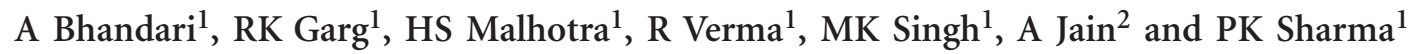

Study design: Cervical spine tuberculosis is a relatively less frequent form of spinal tuberculosis. Cervical spine tuberculosis has a greater propensity to involve the spinal cord and results in major sensory motor deficit. In this prospective study, we aimed to evaluate the clinical and imaging predictors of outcome in conservatively managed patients.

Methods: In this study, 42 patients of cervical spine tuberculosis were included. Patients were subjected to a detailed clinical evaluation and magnetic resonance imaging. Patients were treated with antituberculosis treatment and were followed up for 18 months. The Modified Barthel index (MBI) was used to assess the disability. Good outcome was defined as MBI >12 and poor outcome as $\mathrm{MBI} \leqslant 12$. Clinical and imaging characteristics were used to analyze the predictors of outcome, using univariate and multivariate analysis.

Results: Four (9.5\%) patients required surgery. Data from 38 patients, who were conservatively managed, were analyzed for predictors of outcome. Among conservatively managed patients, at presentation, 29 patients had an MBI score of $\leqslant 12$. At 18 months, the majority of patients (81.6\%) had a good outcome. On univariate analysis, a duration of illness $>3$ months, a major motor deficit, bladder involvement, flexor spasms, significant cord compression and spinal extension of the abscess were significantly associated with a poor outcome. However, on multivariate analysis significant cord compression $(P=0.003)$ and spinal extension $(P=0.02)$ showed a significant correlation with a poor outcome.

Conclusion: Medical management was effective in cervical spine tuberculosis. Patients with significant cord compression and spinal extension of the abscess showed poorer outcome.

Spinal Cord (2014) 52, 489-493; doi:10.1038/sc.2014.49; published online 22 April 2014

\section{INTRODUCTION}

The cervical spine is relatively less frequently affected by tuberculosis compared with lumbar and thoracic spines. Cervical spine tuberculosis is a distinctly different entity because of several reasons. Cervical spine tuberculosis has a greater propensity to involve the spinal cord, resulting in major sensory motor deficit. ${ }^{1}$ In addition to this, cervical spine tuberculosis, because of a retropharyngeal collection of pus, can produce compression over the trachea, which may lead to respiratory insufficiency. ${ }^{2}$

Controversy exists regarding the preferred treatment of choice. Some experts advocate medical therapy alone and some prefer combination antituberculosis chemotherapy and surgery. Most patients with spinal tuberculosis respond to medical treatment. ${ }^{3}$ Antituberculosis treatment protocols used for treatment of spinal tuberculosis vary from 6 to 18 months. British Medical Research Council studies have indicated that thoracolumbar spinal tuberculosis needs be treated with a combination antituberculosis treatment regimen for 6-9 months. ${ }^{4}$ An Indian study, with a follow-up period of 10 years, observed no significant differences in the clinical and radiological status between patients who received 6 months and those who received 9 months of antituberculosis treatment. ${ }^{5}$ British Medical Research Council studies did not include patients with cervical spinal tuberculosis. Surgery is usually indicated if a patient has progressive neurological deficit, a large paraspinal abscess or severe deformity. ${ }^{3}$
A Cochrane review assessing the role of routine surgery in addition to chemotherapy in spinal tuberculosis also concluded that evidence was insufficient for the routine use of surgery. ${ }^{6}$ The Medical Research Council (MRC) study found no definite advantage of early surgery over medical management. However, they had excluded patients with cervical spine involvement. ${ }^{7}$ In retrospective studies on cervical spine tuberculosis, medical management alone has been tried and found to be associated with a good outcome. Some reports have indicated that patients in whom magnetic resonance imaging (MRI) shows a relatively preserved cord with evidence of myelitis or edema and a predominantly fluid collection in the extradural space respond well to conservative treatment. Patients with extradural compression by granulation tissue with little fluid component compressing or constricting the cord circumferentially with cord edema/myelitis or myelomalacia need early surgical decompression. ${ }^{8}$ Even in patients with cranio-vertebral junction tuberculosis, antituberculosis therapy is the mainstay of treatment along with neck stabilization regardless of the extent of bony destruction. ${ }^{9}$ If atlantoaxial instability is present, surgery may be contemplated. ${ }^{10-12}$ Regarding cervical spinal tuberculosis only limited data, either in the form of isolated cases or small case series, are available. ${ }^{13}$

The aim of this prospective follow-up study was to assess the clinical and imaging predictors of outcome in conservatively managed patients of cervical spine tuberculosis.

${ }^{1}$ Department of Neurology, King George Medical University, Lucknow, India and ${ }^{2}$ Department of Microbiology, King George Medical University, Lucknow, India Correspondence: Professor RK Garg, Department of Neurology, King George Medical University, Lucknow 226003, Uttar Pradesh, India. E-mail: garg50@yahoo.com

Received 25 January 2014; revised 18 March 2014; accepted 22 March 2014; published online 22 April 2014 


\section{MATERIALS AND METHODS}

This study was conducted, between August 2011 and July 2013, in the Department of Neurology, King George Medical University, Lucknow, Uttar Pradesh, India. Tuberculosis is a highly endemic disease in this part of India. India accounts for $26 \%$ of total global tuberculosis cases. Approval of the institutional ethics committee was taken for the study. Prior written informed consent to participate in the study was taken from the patient or the guardian/ relatives.

\section{Inclusion criteria}

Consecutive patients with cervical spinal tuberculosis, presenting as quadriparesis, were enrolled in the study. The diagnosis of cervical spinal tuberculosis was based on characteristic clinical and neuroimaging features. Spinal tuberculosis was considered when a patient presented with the characteristic clinical features of neck pain, constitutional symptoms, localized tenderness and deformity and retropharyngeal abscess. The essential neuroimaging criteria were destruction of two or more contiguous cervical vertebrae and opposed end plates, disc infection, along with a paraspinal mass or abscess ${ }^{14}$ (Figure 1).

\section{Exclusion criteria}

Patients were excluded from the study if there was involvement of other vertebral regions. In addition, patients demonstrating atypical imaging features

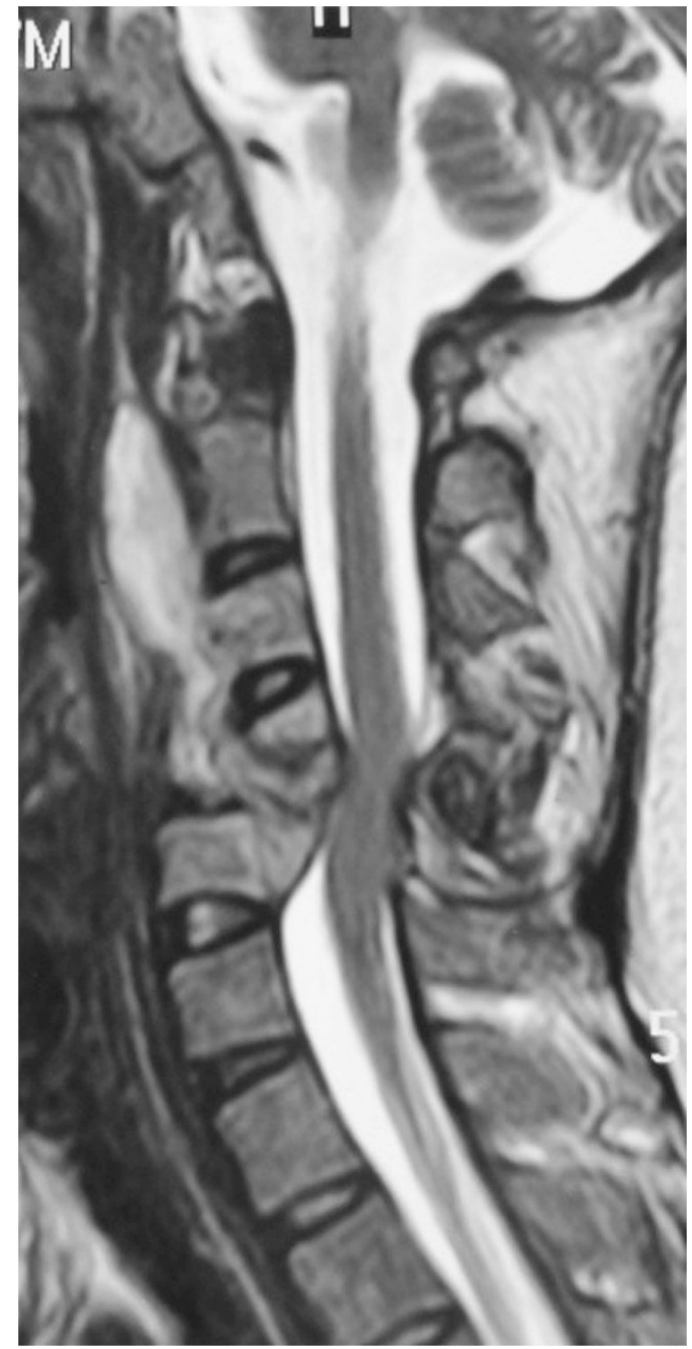

Figure 1 T2-weighted sagittal MRI of a patient showing hyperintense signal changes from $\mathrm{C} 2-\mathrm{C} 6$ vertebral bodies, spondylolisthesis of C5 over C6, prevertebral collection with compression of thecal sac and cord parenchyma. like single vertebral involvement, isolated involvement of posterior spinal segment and non-contiguous vertebral involvement were also excluded.

\section{Workup}

After detailed neurological examination, patients were subjected to a battery of laboratory tests including complete blood counts, blood sugar, liver and renal function tests and the enzyme-linked immunosorbent test for HIV virus. Sputum, if any, was examined for acid-fast bacillus. Chest and cervical spine $\mathrm{X}$-rays were performed. All patients were subjected to gadolinium-enhanced MRI of the cervical spine with a screening of the whole spine using a Signa Excite 1.5 Tesla instrument (General Electric Medical Systems, Milwaukee, WI, USA). An experienced neuroradiologist, blinded to the clinical details of the patients, reviewed the MRI results.

\section{Treatment and follow-up}

Conservative treatment in the form of antituberculosis therapy was given for 18 months. Four drugs (isoniazid, rifampicin, pyrazinamide and ethambutol) were given for 2 months (intensive phase) and two drugs (isoniazid and rifampicin) for the remaining 16 months. ${ }^{15}$ Necks of the patients were immobilized with a rigid cervical collar. Analgesics were provided to control pain. Follow-up evaluation was carried out at 1, 6, 12 and 18 months.

Patients with worsening of the neurological deficit, a large retropharyngeal abscess causing dysphagia or respiratory distress or with atlantoaxial instability were considered for surgical intervention (in consultation with the neurosurgeon).

\section{Functional status assessment}

The modified Barthel index (maximum score 20) was used to assess the outcome. Patients having an MBI score of 13-20 were considered to have a good outcome and those with a score of $0-12$ at 18 months were considered to have a poor outcome.

\section{Definitions}

A minor motor deficit was defined as muscle power $>$ grade 4 (by MRC grading system), whereas a major motor deficit was defined as muscle power $\leqslant$ grade 4 (by MRC grading system). Significant cord compression was defined as $>50 \%$ canal encroachment.

\section{Statistical analysis}

The data were analyzed using SPSS software version 16.0 (SPSS Inc, Chicago, IL, USA). The results are presented in percentages. The change in the MBI score during follow-up was statistically evaluated with the help of McNemar's test. The Chi-square test was used to find out the association between two dichotomous variables. The relative risk with its $95 \%$ confidence interval was calculated. Multivariate logistic regression analysis was performed to find out significant factors associated with the outcome. Clinical variables included in the statistical analysis were age, gender, symptom duration, weakness, sensory involvement, bladder involvement, deformity, history/concomitant tuberculosis, spasticity, hyper-reflexia and flexor spasms. Imaging parameters included number of vertebrae involved, loss of vertebral height, disc space reduction, paravertebral collection, signal changes in cord, significant cord compression, complete vertebral collapse and spinal extension of abscess. A $P$-value $<0.05$ was regarded as significant.

\section{RESULTS}

In this study, 46 consecutive patients of cervical spinal tuberculosis were enrolled. Four patients were lost to follow-up. Thus, 42 patients were included. Four $(9.5 \%)$ patients were subjected to surgery. Data from 38 patients, who were conservatively managed, were analyzed for the predictors of outcome (Figure 2).

\section{Baseline characteristics}

Mean age of the study group was 32.8 years with a range of 8-76 years. The majority of cases $(63.2 \%)$ presented within 3 months of 
Screening of 57 patients with possible cervical spine tuberculosis

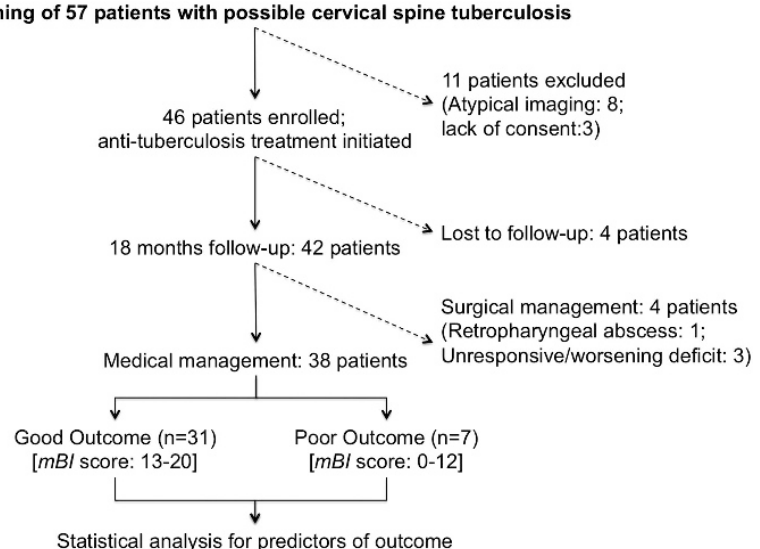

Figure 2 Flowchart of the study.

symptom onset. Mean symptom duration prior to presentation was 3.8 months. All patients had neck pain of varying degrees. In this study, $47.4 \%$ of patients had major motor deficit. The 5 th cervical vertebra was the most common vertebra involved. Loss of vertebral height and disc space reduction were noted in the majority (84.2\%) of patients. Significant cord compression was observed in $52.6 \%$ of cases. Baseline characteristics have been provided in Table 1.

\section{Disability status and follow-up}

Among four surgically managed patients, three patients had poor response to medical treatment and one patient had dysphagia due to a large retropharyngeal abscess (Table 2 ).

At presentation, among 38 conservatively managed patients, 29 had an MBI score of $0-12$. At the 12-month follow-up, only 13 patients remained in the group with a disability score of $0-12$ and the rest improved to a score of 13-20. After 18 months, the majority of patients $(81.6 \%)$ had a good outcome.

\section{Predictors of outcome}

On univariate analysis, a duration of illness $>3$ months, major motor deficit, bladder involvement, flexor spasms, significant cord compression and spinal extension of the abscess were significantly associated with a poor outcome. However, on multivariate analysis, significant cord compression $(P=0.003)$ and spinal extension $(P=0.02)$ had a significant correlation with a poor outcome (Table 3 ). We did not observe any significant effect of specific vertebral segment involvement (Table 4).

\section{DISCUSSION}

We observed that the majority of our patients with cervical spine tuberculosis responded well to medical treatment. Earlier reports have also indicated that, in cervical spinal tuberculosis, medical treatment is effective in restoring the functional status of the patients. ${ }^{13}$ In cranio-vertebral junction tuberculosis, despite extensive erosion of the clivus, $\mathrm{C} 1$ and $\mathrm{C} 2$, and spinal cord compression, the patients can effectively be managed with antituberculosis therapy alone. ${ }^{9,16}$

We could deduce that significant cord compression and spinal extension of abscess were significantly associated with outcome in cervical spine tuberculosis. These observations indicated that extensive tuberculous involvement of the spinal cord was responsible for the poor outcome. Earlier, similar observations were made in patients with thoraco-lumbar spinal tuberculosis as well. In this study,
Table 1 Baseline clinicoradiological characteristics of conservatively treated patients with cervical spinal tuberculosis $(n=38)$

\begin{tabular}{|c|c|c|}
\hline Characteristics & Number & Percentage \\
\hline \multicolumn{3}{|l|}{ Age in years } \\
\hline$\leqslant 15$ & 12 & 31.6 \\
\hline$>15$ & 26 & 68.4 \\
\hline Mean \pm s.d. & \multicolumn{2}{|c|}{$32.84 \pm 20.52(8-76)$} \\
\hline \multicolumn{3}{|l|}{ Gender } \\
\hline Male & 15 & 39.5 \\
\hline Female & 23 & 60.5 \\
\hline \multicolumn{3}{|c|}{ Duration of symptoms (in months) } \\
\hline $0-3$ & 24 & 63.2 \\
\hline$>3$ & 14 & 36.8 \\
\hline Mean \pm s.d. & \multicolumn{2}{|c|}{$3.84 \pm 3.67(0.5-14.0)$} \\
\hline \multicolumn{3}{|l|}{ Motor deficit } \\
\hline Minor & 20 & 52.6 \\
\hline Major & 18 & 47.4 \\
\hline \multicolumn{3}{|c|}{ Sensory involvement } \\
\hline No & 16 & 42.1 \\
\hline Yes & 22 & 57.9 \\
\hline \multicolumn{3}{|l|}{ Bladder } \\
\hline No involvement & 31 & 81.6 \\
\hline Involvement & 7 & 18.4 \\
\hline \multicolumn{3}{|l|}{ Deformity } \\
\hline No & 36 & 94.7 \\
\hline Yes & 2 & 5.3 \\
\hline \multicolumn{3}{|c|}{ History/concomitant tuberculosis } \\
\hline No & 18 & 47.4 \\
\hline Yes & 20 & 52.6 \\
\hline \multicolumn{3}{|l|}{ Spasticity } \\
\hline No & 11 & 28.9 \\
\hline Yes & 27 & 71.1 \\
\hline \multicolumn{3}{|l|}{ Hyper-reflexia } \\
\hline No & 5 & 13.2 \\
\hline Yes & 33 & 86.8 \\
\hline \multicolumn{3}{|l|}{ Flexor spasm } \\
\hline No & 29 & 76.3 \\
\hline Yes & 9 & 23.7 \\
\hline \multicolumn{3}{|c|}{ No. of vertebra involved } \\
\hline 2 & 11 & 28.9 \\
\hline$\geqslant 3$ & 27 & 71.1 \\
\hline \multicolumn{3}{|c|}{ Loss of vertebral height } \\
\hline No & 6 & 15.8 \\
\hline Yes & 32 & 84.2 \\
\hline \multicolumn{3}{|c|}{ Disc space reduction } \\
\hline No & 6 & 15.8 \\
\hline Yes & 32 & 84.2 \\
\hline \multicolumn{3}{|c|}{ Paravertebral collection } \\
\hline No & 0 & 0 \\
\hline Yes & 38 & 100 \\
\hline \multicolumn{3}{|c|}{ Signal changes in cord } \\
\hline No & 23 & 60.5 \\
\hline Yes & 15 & 39.5 \\
\hline Cord compression & & \\
\hline No & 18 & 47.4 \\
\hline Yes & 20 & 52.6 \\
\hline Complete vertebral & & \\
\hline No & 31 & 81.6 \\
\hline Yes & 7 & 18.4 \\
\hline Spinal extension o & & \\
\hline No & 18 & 47.4 \\
\hline Yes & 20 & 52.6 \\
\hline
\end{tabular}


Table 2 Profile of patients with cervical spine tuberculosis who were surgically managed

\begin{tabular}{|c|c|c|c|c|}
\hline Characteristics & Patient 1 & Patient 2 & Patient 3 & Patient 4 \\
\hline Age (years) & 45 & 28 & 15 & 35 \\
\hline Sex & Male & Female & Female & Male \\
\hline $\begin{array}{l}\text { Duration of } \\
\text { symptoms } \\
\text { (months) }\end{array}$ & 2 & 12 & 6 & 5 \\
\hline Motor deficit & Major & Major & Major & Major \\
\hline Sensory deficit & No & Yes & Yes & Yes \\
\hline $\begin{array}{l}\text { Bladder } \\
\text { involvement }\end{array}$ & No & Yes & Yes & Yes \\
\hline $\begin{array}{l}\text { Cord signal } \\
\text { changes }\end{array}$ & Yes & Yes & Yes & Yes \\
\hline $\begin{array}{l}\text { Significant cord } \\
\text { compression }\end{array}$ & Yes & Yes & Yes & Yes \\
\hline $\begin{array}{l}\text { Spinal extension } \\
\text { of abscess }\end{array}$ & Yes & Yes & Yes & Yes \\
\hline $\begin{array}{l}\text { Initial Barthel } \\
\text { index }\end{array}$ & $<12$ & $<12$ & $<12$ & $<12$ \\
\hline $\begin{array}{l}\text { Vertebrae } \\
\text { involved }\end{array}$ & $\mathrm{C} 5$ and $\mathrm{C} 6$ & C5-C7 & C3-C5 & $\mathrm{C} 5-\mathrm{C} 7$ \\
\hline $\begin{array}{l}\text { Indication for } \\
\text { surgery }\end{array}$ & $\begin{array}{c}\text { Dysphagia } \\
\text { due to retro- } \\
\text { pharyngeal } \\
\text { abscess }\end{array}$ & $\begin{array}{c}\text { Spine } \\
\text { deformity, no } \\
\text { improvement } \\
\text { on medical } \\
\text { therapy }\end{array}$ & $\begin{array}{l}\text { Deterioration } \\
\text { despite } \\
\text { medical } \\
\text { therapy }\end{array}$ & $\begin{array}{c}\text { Deterioration } \\
\text { despite } \\
\text { medical } \\
\text { therapy }\end{array}$ \\
\hline Intervention & $\begin{array}{l}\text { Trans-oral } \\
\text { drainage }\end{array}$ & $\begin{array}{l}\text { C6 corpectomy } \\
\text { with } \mathrm{C} 5-\mathrm{C} 7 \\
\text { anterior } \\
\text { cervical } \\
\text { plating with } \\
\text { iliac bone } \\
\text { grafting }\end{array}$ & $\begin{array}{c}\text { Epidural } \\
\text { decompression } \\
\& \text { Drainage of } \\
\text { pre/para- } \\
\text { vertebral } \\
\text { collection }\end{array}$ & $\begin{array}{l}\text { C6 and C7 } \\
\text { partial } \\
\text { corpectomy } \\
\text { with C5-C7 } \\
\text { anterior } \\
\text { cervical } \\
\text { plating }\end{array}$ \\
\hline
\end{tabular}

Table 3 Outcome assessment according to cervical vertebral segment involvement in conservatively treated patients with cervical spinal tuberculosis $(n=38)$

\begin{tabular}{|c|c|c|c|c|c|c|c|c|}
\hline \multirow[t]{4}{*}{ Groups } & \multicolumn{8}{|c|}{$M B I$} \\
\hline & \multicolumn{4}{|c|}{ Baseline MBI } & \multicolumn{4}{|c|}{$\mathrm{MBI}$ at 18 months } \\
\hline & \multicolumn{2}{|c|}{$0-12$} & \multicolumn{2}{|c|}{$13-20$} & \multicolumn{2}{|c|}{$0-12$} & \multicolumn{2}{|c|}{$13-20$} \\
\hline & No. & $\%$ & No. & $\%$ & No. & $\%$ & No. & $\%$ \\
\hline C1or C2 and below $(n=6)$ & 4 & 66.7 & 2 & 33.3 & 0 & 0 & 6 & 100.0 \\
\hline C3or C4 and below $(n=10)$ & 5 & 50.0 & 5 & 50.0 & 2 & 20.0 & 8 & 80.0 \\
\hline C5 and below $(n=22)$ & 20 & 90.9 & 2 & 9.1 & 5 & 22.7 & 17 & 77.3 \\
\hline$P$-value & \multicolumn{4}{|c|}{0.03} & \multicolumn{4}{|c|}{0.44} \\
\hline
\end{tabular}

Abbreviation: MBI, modified Barthel index.

significant spinal cord compression by granulation tissue resulted in severe disabilities and was associated with poorer outcome. ${ }^{17}$

Cervical spinal cord lesions often cause severe neurologic deficit because the cervical spinal canal is small in relation to the diameter of the cervical spinal cord. The proposed mechanisms responsible for neurologic manifestations in cervical spine tuberculosis are as follows: local inflammatory changes, cord swelling, vasculitis and ischemia in spinal cord parenchyma, subluxation of the vertebrae, tuberculous abscess compressing over the spinal cord or nerve root, and disc herniation. MRI abnormalities like spinal cord edema or myelitis were associated with good outcome, possibly because these abnormalities were reversible. ${ }^{18}$ The patients showing a relatively preserved cord
Table 4 Significant predictors of good outcome (change in MBI score from 0-12 to 13-20) in conservatively treated patients with cervical spinal tuberculosis $(n=38)$

\begin{tabular}{|c|c|c|c|c|}
\hline \multirow[t]{2}{*}{ Factors } & \multirow[t]{2}{*}{ No. of patients } & \multicolumn{2}{|c|}{ Converted } & \multirow[t]{2}{*}{ RR (95\% Cl), P-value } \\
\hline & & No. & $\%$ & \\
\hline $\begin{array}{l}\text { Age in years } \\
\quad \leqslant 15 \\
\quad>15\end{array}$ & $\begin{array}{l}12 \\
26\end{array}$ & $\begin{array}{r}7 \\
15\end{array}$ & $\begin{array}{l}58.3 \\
57.7\end{array}$ & $\begin{array}{c}1.01(0.56-1.80), 0.97 \\
1.00 \text { (Ref) }\end{array}$ \\
\hline $\begin{array}{l}\text { Gender } \\
\text { Male } \\
\text { Female }\end{array}$ & $\begin{array}{l}15 \\
23\end{array}$ & $\begin{array}{l}11 \\
11\end{array}$ & $\begin{array}{l}73.3 \\
47.8\end{array}$ & $\begin{array}{c}1.53(0.90-2.59), 0.12 \\
1.00 \text { (Ref) }\end{array}$ \\
\hline $\begin{array}{l}\text { Duration of sympto } \\
\quad \begin{array}{l}0-3 \\
>3\end{array}\end{array}$ & $\begin{array}{c}\text { ns (in month) } \\
24 \\
14\end{array}$ & $\begin{array}{r}19 \\
3\end{array}$ & $\begin{array}{l}79.2 \\
21.4\end{array}$ & $\begin{array}{c}3.69 \text { (1.32-3.28), } 0.001 \text { * } \\
1.00 \text { (Ref) }\end{array}$ \\
\hline $\begin{array}{l}\text { Motor deficit } \\
\text { Minor } \\
\text { Major }\end{array}$ & $\begin{array}{l}20 \\
18\end{array}$ & $\begin{array}{r}15 \\
7\end{array}$ & $\begin{array}{l}75.0 \\
38.9\end{array}$ & $\begin{array}{c}1.92 \text { (1.02-3.62), } 0.02 * \\
1.00 \text { (Ref) }\end{array}$ \\
\hline $\begin{array}{l}\text { Sensory involveme } \\
\text { Yes } \\
\text { No }\end{array}$ & $\begin{array}{l}22 \\
16\end{array}$ & $\begin{array}{l}10 \\
12\end{array}$ & $\begin{array}{l}45.5 \\
75.0\end{array}$ & $\begin{array}{c}0.60(0.36-1.03), 0.06 \\
1.00 \text { (Ref) }\end{array}$ \\
\hline $\begin{array}{l}\text { Bladder } \\
\quad \text { No involvement } \\
\text { Involvement }\end{array}$ & $\begin{array}{r}31 \\
7\end{array}$ & $\begin{array}{r}21 \\
1\end{array}$ & $\begin{array}{l}67.7 \\
14.3\end{array}$ & $\begin{array}{c}4.74(0.76-29.58), 0.01 \text { * } \\
1.00 \text { (Ref) }\end{array}$ \\
\hline $\begin{array}{l}\text { Deformity } \\
\text { Yes } \\
\text { No }\end{array}$ & $\begin{array}{r}2 \\
36\end{array}$ & $\begin{array}{r}1 \\
21\end{array}$ & $\begin{array}{l}50.0 \\
58.3\end{array}$ & $\begin{array}{c}0.85(0.20-3.52), 0.81 \\
1.00 \text { (Ref) }\end{array}$ \\
\hline $\begin{array}{l}\text { History/concomitan } \\
\text { Yes } \\
\text { No }\end{array}$ & $\begin{array}{c}\text { pulmonary } T B \\
20 \\
18\end{array}$ & $\begin{array}{l}10 \\
12\end{array}$ & $\begin{array}{l}50.0 \\
66.7\end{array}$ & $\begin{array}{c}0.75 \text { (0.43-1.29), } 0.29 \\
\quad 1.00 \text { (Ref) }\end{array}$ \\
\hline $\begin{array}{l}\text { Spasticity } \\
\text { Yes } \\
\text { No }\end{array}$ & $\begin{array}{l}27 \\
11\end{array}$ & $\begin{array}{r}13 \\
9\end{array}$ & $\begin{array}{l}48.1 \\
81.8\end{array}$ & $\begin{array}{c}0.58(0.36-0.95), 0.05 \\
1.00 \text { (Ref) }\end{array}$ \\
\hline $\begin{array}{l}\text { Hyper-reflexia } \\
\text { Yes } \\
\text { No }\end{array}$ & $\begin{array}{r}33 \\
5\end{array}$ & $\begin{array}{r}19 \\
3\end{array}$ & $\begin{array}{l}57.6 \\
60.0\end{array}$ & $\begin{array}{c}0.96 \text { (0.44-2.07), } 0.91 \\
1.00 \text { (Ref) }\end{array}$ \\
\hline $\begin{array}{l}\text { Flexor spasm } \\
\text { Yes } \\
\text { No }\end{array}$ & $\begin{array}{r}9 \\
29\end{array}$ & $\begin{array}{r}1 \\
21\end{array}$ & $\begin{array}{l}11.1 \\
72.4\end{array}$ & $\begin{array}{c}0.15(0.02-0.98), 0.001 \text { * } \\
1.00 \text { (Ref) }\end{array}$ \\
\hline $\begin{array}{l}\text { No. of vertebra inv } \\
2 \\
\geqslant 3\end{array}$ & $\begin{array}{l}11 \\
27\end{array}$ & $\begin{array}{r}4 \\
18\end{array}$ & $\begin{array}{l}36.4 \\
66.7\end{array}$ & $\begin{array}{c}0.54(0.23-1.24), 0.08 \\
1.00 \text { (Ref) }\end{array}$ \\
\hline $\begin{array}{l}\text { Loss of vertebral } h \\
\text { Yes } \\
\text { No }\end{array}$ & $\begin{array}{r}32 \\
6\end{array}$ & $\begin{array}{r}18 \\
4\end{array}$ & $\begin{array}{l}56.2 \\
66.7\end{array}$ & $\begin{array}{c}0.84(0.44-1.60), 0.63 \\
1.00 \text { (Ref) }\end{array}$ \\
\hline $\begin{array}{l}\text { Disc space reducti } \\
\text { Yes } \\
\text { No }\end{array}$ & $\begin{array}{r}32 \\
6\end{array}$ & $\begin{array}{r}17 \\
5\end{array}$ & $\begin{array}{l}53.1 \\
83.3\end{array}$ & $\begin{array}{c}0.63(0.39-1.03), 0.16 \\
1.00 \text { (Ref) }\end{array}$ \\
\hline $\begin{array}{l}\text { Paravertebral colle } \\
\text { Yes } \\
\text { No }\end{array}$ & $\begin{array}{r}38 \\
0\end{array}$ & $\begin{array}{r}22 \\
0\end{array}$ & $\begin{array}{r}57.9 \\
0.0\end{array}$ & $\begin{array}{c}\text { NA } \\
1.00 \text { (Ref) }\end{array}$ \\
\hline $\begin{array}{l}\text { Signal changes in } \\
\text { Yes } \\
\text { No }\end{array}$ & $\begin{array}{l}15 \\
23\end{array}$ & $\begin{array}{l}10 \\
10\end{array}$ & $\begin{array}{l}66.7 \\
52.2\end{array}$ & $\begin{array}{c}1.27(0.75-2.17), 0.37 \\
1.00 \text { (Ref) }\end{array}$ \\
\hline $\begin{array}{l}\text { Cord compression } \\
\text { Yes } \\
\text { No }\end{array}$ & $\begin{array}{l}20 \\
18\end{array}$ & $\begin{array}{r}7 \\
15\end{array}$ & $\begin{array}{l}35.0 \\
83.3\end{array}$ & $\begin{array}{c}0.42(0.22-0.79), 0.003 * \\
1.00 \text { (Ref) }\end{array}$ \\
\hline $\begin{array}{l}\text { Complete collapse } \\
\text { Yes } \\
\text { No }\end{array}$ & $\begin{array}{r}7 \\
31\end{array}$ & $\begin{array}{r}2 \\
20\end{array}$ & $\begin{array}{l}28.6 \\
64.5\end{array}$ & $\begin{array}{c}0.44(0.13-1.47), 0.08 \\
1.00 \text { (Ref) }\end{array}$ \\
\hline $\begin{array}{l}\text { Spinal extension } \\
\text { Yes } \\
\text { No }\end{array}$ & $\begin{array}{l}20 \\
18\end{array}$ & $\begin{array}{r}7 \\
15\end{array}$ & $\begin{array}{l}35.0 \\
83.3\end{array}$ & $\begin{array}{c}0.42(0.22-0.79), 0.003 * \\
1.00 \text { (Ref) }\end{array}$ \\
\hline
\end{tabular}

Abbreviations: $\mathrm{Cl}$, Confidence Interval; RR, Relative risk; Ref, Reference; TB, tuberculosis. *Significant. 
Patients diagnosed with cervical spine tuberculosis

$$
\downarrow
$$

Significant cord compression ( $>50 \%$ canal encroachment ) and/or spinal extension of the abscess

$\stackrel{\text { Yes }}{\longrightarrow}$ Consider early surgical intervention with ATT

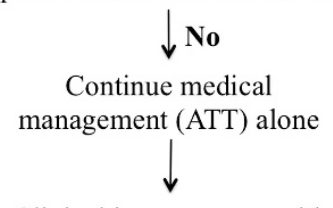

Clinical improvement with 4 to 6 weeks of ATT

$$
\downarrow \text { No }
$$

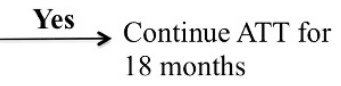

Major motor, bowel or bladder deficit/ progressive dyspnea or dysphagia

Consider surgical intervention with continuation of ATT

Figure 3 Proposed algorithm for managing patients with tuberculosis of the cervical spine. ATT, antituberculosis therapy.

with evidence of edema/myelitis with fluid collection predominantly in the extradural space on MRI recover on medical treatment, whereas patients with extradural compression of mixed or granulomatous nature showing encasement of the spinal cord may be considered for surgery. ${ }^{17}$

Four of our patients were subjected to surgery. Three patients had not responded to medical treatment while one developed a swallowing problem. In patients with cervical spine tuberculosis, surgical treatment is usually contemplated if there is a progressive neurological deficit. ${ }^{19}$ Experts recommend that patients with cranio-vertebral junction tuberculosis who fail to respond to 4-6 weeks of antituberculosis treatment and skull traction should be offered surgery. ${ }^{20}$ Debridement and decompression of the spinal canal along with fixation of the affected spinal segments can effectively remove compressive granulation tissues, decompress the neuronal structures and restore the spinal structure and stability. ${ }^{3}$ A randomized study is needed to establish the exact role of surgery in patients with cervical spine tuberculosis (Figure 3).

\section{CONCLUSION}

Medical management is effective in cervical spine tuberculosis. Patients with significant cord compression and spinal extension of the abscess show poorer outcome and might be candidates for early surgical intervention.

\section{DATA ARCHIVING}

There were no data to deposit.

\section{CONFLICT OF INTEREST}

The authors declare no conflict of interest.

1 Hsu LC, Leong JC. Tuberculosis of the lower cervical spine (C2 to C7). A report on 40 cases. J Bone Joint Surg Br 1984; 66: 1-5.

2 Diom ES, Ndiaye C, Djafarou AB, Ndiaye IC, Faye PM, Tall A et al. A case of cervical Pott's disease revealed by parapharyngeal abscess. Eur Ann Otorhinolaryngol Head Neck Dis 2011; 128: 151-153.

3 Garg RK, Somvanshi DS. Spinal tuberculosis: a review. J Spinal Cord Med 2011; 34: 440-454.

4 Cheung WY, Luk KD. Clinical and radiological outcomes after conservative treatment of TB spondylitis: is the 15 years' follow-up in the MRC study long enough? Eur Spine $J$ 2013; 22 (Suppl 4), 594-602.

5 Parthasarathy R1, Sriram K, Santha T, Prabhakar R, Somasundaram PR, Sivasubramanian S. Short-course chemotherapy for tuberculosis of the spine. A comparison between ambulant treatment and radical surgery - ten-year report. J Bone Joint Surg Br 1999; 81: 464-471.

6 Jutte PC, Van Loenhout-Rooyackers JH. Routine surgery in addition to chemotherapy for treating spinal tuberculosis. Cochrane Database Syst Rev 2006; 25: CD00453.

7 MRC Working Party on Tuberculosis of the Spine. Five-year assessment of controlled trials of short-course chemotherapy regimens of 6,9 or 18 months' duration for spinal tuberculosis in patients ambulatory from the start or undergoing radical surgery: Fourteenth report of the Medical Research Council Working Party on Tuberculosis of the Spine. Int Orthop 1999; 23: 73-81.

8 Jain AK, Dhammi IK. Tuberculosis of the spine: a review. Clin Orthop Relat Res 2007; 460: $39-49$.

9 Arora S, Sabat D, Maini L, Sural S, Kumar V, Gautam VK et al. The results of nonoperative treatment of craniovertebral junction tuberculosis: a review of twenty-six cases. J Bone Joint Surg Am 2011; 93: 540-547.

10 Shukla D, Mongia S, Devi BI, Chandramouli BA, Das BS. Management of craniovertebral junction tuberculosis. Surg Neurol 2005; 63: 101-106.

11 Teegala R, Kumar P, Kale SS, Sharma BS. Craniovertebral junction tuberculosis: a new comprehensive therapeutic strategy. Neurosurgery 2008; 63: 946-955.

12 Chadha M, Agarwal A, Singh AP. Craniovertebral tuberculosis: a retrospective review of 13 cases managed conservatively. Spine (Phila Pa 1976) 2007; 32: 1629-1634.

13 Elsawaf A. Outcome of surgical versus conservative management of cervical spine myelopathy secondary to cervical tuberculosis. Neurosurg Rev 2013; 36: 621-628.

14 Wang X-Y, Luo C-K, Li W-W, Wu P, Pang X-Y, Xu Z-Q et al. A practical therapeutic protocol for cervical tuberculosis. Eur J Trauma Emerg Surg 2013; 39: 93-99.

15 Thwaites GE, Fisher M, Hemingway C, Scott G, Solomon T, Innes J, British Infection Society. British Infection Society guidelines for the diagnosis and treatment of tuberculosis of the central nervous system in adults and children. J Infect 2009; 59: 167-187.

16 Gupta SK, Mohindra S, Sharma BS, Gupta R, Chhabra R, Mukherjee KK et al. Tuberculosis of the craniovertebral junction: is surgery necessary? Neurosurgery 2006; 58: 1144-1150.

17 Garg RK, Raut T, Malhotra HS, Parihar A, Goel M, Jain A et al. Evaluation of prognostic factors in medically treated patients of spinal tuberculosis. Rheumatol Int 2013; 33: 3009-3015.

18 Jain AK, Kumar J. Tuberculosis of spine: neurological deficit. Eur Spine J 2013; 22 (Suppl 4), 624-633.

19 Qureshi MA, Afzal W, Khalique AB, Pasha IF, Aebi M. Tuberculosis of the craniovertebral junction. Eur Spine J 2013; 22 (Suppl 4), 612-617.

20 Ding Q, Liu Z, Sun X, Ji ML, Wang B, Qiu Y. Isolated extradural tuberculous granuloma of the cervical spine: a case report. Eur Spine J 2012; 21 (Suppl 4), S467-S470. 